\title{
Awareness about climate change adaptation through mobile applications
}

\begin{abstract}
A major task of adaptation is to spread awareness to the individual level and to collect individual response or reaction to climate change. ICTs specifically mobile applications have the potential to raise awareness but its scope has not been much discussed yet. No doubt the world economy has invested much to conduct awareness raising campaigns, environmental education and trainings to promote climate awareness, but the results are not satisfactory enough. Mobile phone penetration rates are relatively high in developing countries (28\% for the period 2013-2017) and there are many examples of how simple mobile phone warnings saved several lives in environmental disasters. ICT in particular is useful as an alert mechanism and is considered faster than the conventional mass media. Hence, its high time that organisations working day in and day out to deal with the issue of climate change adaptation come together and contemplate over the usefulness of using mobile applications in spreading awareness through mobile applications. Apart from spreading awareness, they can be also useful in collecting data at individual level regarding the effects of climate change on each of them through applications, which would in return provide them solutions to deal with such situations and help the policy makers and researchers to come up with a better statistics for further reference and analysis.
\end{abstract}

Keywords: mobile application, adaptation, climate change, analysis, celsius
Volume 2 Issue 7 - 2017

\author{
Madhurima Chakraborty,' Debalina \\ Chakravarty ${ }^{2}$ \\ 'Senior Systems Engineer, Infosys Limited and Alumni of \\ Department of Information Technology, RCC Institute of \\ Information Technology, India \\ ${ }^{2}$ Faculty, Department of HSSM, National Institute of Technology, \\ India
}

Correspondence: Debalina Chakravarty, Faculty, Department of HSSM, National Institute of Technology, Jamshedpur -831014 , India,

Email dchakravarty.hum@nitjsr.ac.in, c.debalina85@gmail.com

Received: November 03, 2017 | Published: December 05, 2017

\section{Introduction}

The Paris agreement signed on 22nd April, 2016 primarily aimed to deal with the serious threats of climate change by keeping the global temperature increase below 2 degree Celsius and going forward if possible, below 1.5 degree Celsius. As a consequence, the increasingly stringent climate change policies call for even more rapid and effective adaptation and mitigation strategies. Any strategy or policy taken towards keeping global temperature rise below 2 degree Celsius or even lower will not be effective enough unless the general public is well aware of $i^{1}$ and does not contribute to the destruction of the current scenario any further. While the Paris agreement demands the countries to take actions on climate change adaptation and mitigation policies, the former would supposedly take some time considering it is a long term process, whereas the latter involves quick responses to limit the effects of climate change on us. ${ }^{2-4}$ In fact, a prime objective of adaptation studies is to spread awareness to the individual level ${ }^{5}$ and to collect individual response or reaction to climate change. ${ }^{6}$

Information and Communication Technologies (ICTs) is defined as the study, design, development, implementation, support or management of software application-based information systems (Information Technology Association of America, 2008). The primary objectives of ICT are to record data \& information, to transform the data \& information into knowledge for common people and to communicate. Mobile applications, particularly, which are basically a set of easy to operate, inexpensive rather cost-effective programs running on a mobile device to perform a certain task ${ }^{7}$ may serve as an important medium for raising awareness. ${ }^{8}$ ICTs has effective and significant potential in the fields of climate change and in the search of solutions for complex problem of climate change. ${ }^{9,10}$ Although, researcher had identified that the use of application of ICTs in the climate change domain is limited to a large extent. In this article we would try to identify the opportunities of ICTs specifically mobile applications in spreading awareness about climate change adaptation and examine the status of current and emerging processes to raise public awareness. Here, we would be talking about why and how mobile applications strategy of climate changes with the help of examples/cases from developing countries. The study is organized in the following manner. First section elaborates the background and context of the study. Next section presents the opportunities of the ICTs in facilitating climate change awareness and data. The final section summarizes the findings of the analysis highlighting the scope of expansion of the present study.

\section{Opportunities of the ICTs in facilitating climate change awareness and data}

Literature often identifies that adaptation measures are only responsibilities of the national and governmental bodies, however, Climate Change Adaptation Strategies for Local Impact, UNFCCC ${ }^{11}$ rightly points out how the citizens and businesses are key factors in achieving real impact on the ground. UNEP points out in UNEP climate change strategy, 2008 that helping governments, industry and the public to make sense of the plethora of information that has been made available to them through media and take informed actions has always been challenging for them. The citizens can be of great help by implementing the adaptation policies in their daily lives and participating in and cooperating with the local governments. ${ }^{12}$ Even though public participation has been promoted as an important driving factor in formulating responses to climate change risks by multiple research groups,${ }^{13}$ the practice itself has not been exploited to its best. No doubt the world economy has invested much to conduct awareness raising campaigns, environmental education and trainings to promote climate awareness, including campaigns like Billion Tree Campaign, Climate Neutral Network and celebrating special days like World Environment Day and the results are not satisfactory enough. ${ }^{14,15}$ We need to persuade the crowd harder and better and 
considering the popularity of the mobile applications in our present day, there can be no better alternative to sensitise them about the risks of climate change and importance of climate change adaptation. For example, the e-Arik project points out in their learnings from the 'Village Knowledge Centre' that use of mobile phones in general awareness-raising and individual assistance would have been a better idea. ${ }^{16}$ The mobile internet user base which was 306 million on December 2015, was expected to grow by a percent of 21 in six months touching 371 million users in June, 2016 constituting of 262 million of urban mobile internet users, which is 71 percent of the number and 109 million of rural mobile internet users in India. ${ }^{17}$ Now, households even in the rural parts of the countries own at least a cell phone. Government of India reports in its Census, 2011 that around $70 \%$ of households in the rural areas of India itself owns one cell phone for minimum. Hence, rather than investing in setting up a whole institution along with digital facilities and training personnel to use and impart education through them; providing customized information over calls and general ideas through mobile applications can be more cost effective. For instance, it is estimated that the total cost incurred by the eArik project was Rs. $1.26 \mathrm{mn}$ from 2007 to 2011. Had they implemented the use of ICTs through mobile applications effectively, the cost incurred could have been notably low. Although we must keep in mind that a part of the population is yet to be familiar with smart phones and mobile applications and therefore, we need to cater the audience based on their ability to learn, afford and use the technologies in their daily life but the good thing is that uptake rate of mobile applications is significantly high, CAGR (compound annual growth rate) is estimated to be $28 \%$ from 2013 to 2017.

The recent advances of ICT in space based systems, Geographical Information Systems (GIS), wireless broadband technologies, Wireless Sensor Networks (WSN), mobile (cellular) technology and soft technologies such as Web-based tools (i.e. Web 2.0) and information systems have resulted in development of several mobile applications utilising the same information as well. Though they are relatively new, but several successful pilot programs have been run around the world, and the range of applications is diverse. In fact, NASA (The National Aeronautics and Space Administration) has also recently launched an educational game, 'Offset' that informs the players about the global carbon cycle, the different carbon sources and the ways alternative energy and reforestation can help counteract those sources. The national meteorological centres and other specialised ones already carry out several systematic observations to study the climate changes through regular monitoring of atmosphere, ocean and terrestrial systems..$^{18}$ The systems are intelligent enough to monitor particular environmental cues, such as temperature, light intensity, water levels, local meteorological data and pollutant level. ${ }^{19}$ But, in developing countries these information mostly stay restricted with the concerned stakeholders in the era of 'Right to Information'.

Table I List of widely used mobile application for generating awareness about climate change adaptation

\begin{tabular}{|c|c|c|}
\hline Application & Developer & Function \\
\hline Climate Change Awareness & Clima Tech & $\begin{array}{l}\text { Provides information about climate change to create awareness. Information typically } \\
\text { includes causes and effects of Climate Change, answers to the most commonly asked } \\
\text { questions on Global Warming, well researched question bank on diverse topics of } \\
\text { environment etc. }\end{array}$ \\
\hline Global Warming Climate Change & \multicolumn{2}{|l|}{ Nicholas Gabriel } \\
\hline MP Climate Change & \multicolumn{2}{|c|}{ One World Foundation, India } \\
\hline Climate Change & \multicolumn{2}{|l|}{ Francesco Salamone } \\
\hline Green IQ & \multicolumn{2}{|l|}{ TERI, India } \\
\hline WB Climate (World Bank) & \multicolumn{2}{|l|}{ Ams Challenges } \\
\hline Carbon Sins & $\begin{array}{l}\text { Team Maple } \\
\text { Bangalore, India }\end{array}$ & Provides effective measures to reduce Carbon Footprint, pollution etc. \\
\hline Green Tips & \multicolumn{2}{|l|}{ Mobilendo } \\
\hline Survive Global Climate Change & $\begin{array}{l}\text { Kendall College of } \\
\text { Art and Design }\end{array}$ & $\begin{array}{l}\text { Presents animated stories of survival situations that may be caused in future by global } \\
\text { climate change including pollution, rising sea waters and trains the users on how to survive } \\
\text { such situations and what they can do now to prevent this from becoming a reality. }\end{array}$ \\
\hline The Changing Climate Technovation & Hisarcs & Attempts to create awareness about climate change through different games. \\
\hline Spatial Agent & World Bank & $\begin{array}{l}\text { Improves mass awareness using a range of multi-sectoral spatial and temporal data from a } \\
\text { variety of institutions }\end{array}$ \\
\hline Carbon To Soil & Space Nation & $\begin{array}{l}\text { Gives everyone the chance to participate in reverse climate change by creating awareness } \\
\text { and monitor regenerative farming in the real world. }\end{array}$ \\
\hline
\end{tabular}

Source: Author's compilation.

Most people in developing countries obtain climate contingency related information either through combined word of mouth, traditional knowledge or local media sources. Radio remains the main channel for providing information to large sections of population, ${ }^{20}$ be it disaster warnings or awareness communications. Televisions are also used as an alternative to raise awareness regarding climate change ${ }^{21}$ but capacity to reach mass people in the remote places is restricted. Proliferation of channels, and extension of warnings to those not listening/viewing are also issues and now that we have still have the majority of the change makers ignorant of the consequences of the climate change, we may consider mobile applications to invade the space and send general updates on climate change based on their location from time to time along with the actions they may take to address the issue. Smart Mobile phone penetration rates are relatively high in developing countries $(28 \%)$ and there are many examples of how simple mobile phone warnings saved several lives in environmental disasters..$^{22,23}$ For example, the cyclone information system, an initiative by Government of India has already resulted in a reduction in loss of life and property, in the cases of the severe cyclonic storms like Phailin which crossed Odisha coast 
near Gopalpur in October 2013 and the Hudhud in Andhra Pradesh coast near Visakhapatnam in October 2014. The initiative was entirely Short Messaging Service (SMS) application based and had comparatively minimised loss of lives and resources in both these cyclonic storms. Mobile applications including SMS in particular are useful as an alert mechanism and are considered to be faster than the conventional mass media. ${ }^{24}$ The Negotiator App offered by UNFCCC is another application which works as an awareness communication offering the latest news about the climate talks, along with alerts to their live webcasts of sessions and press conferences, and access to official documents, agendas and programmes of meetings, side events and exhibits. ${ }^{25-28}$

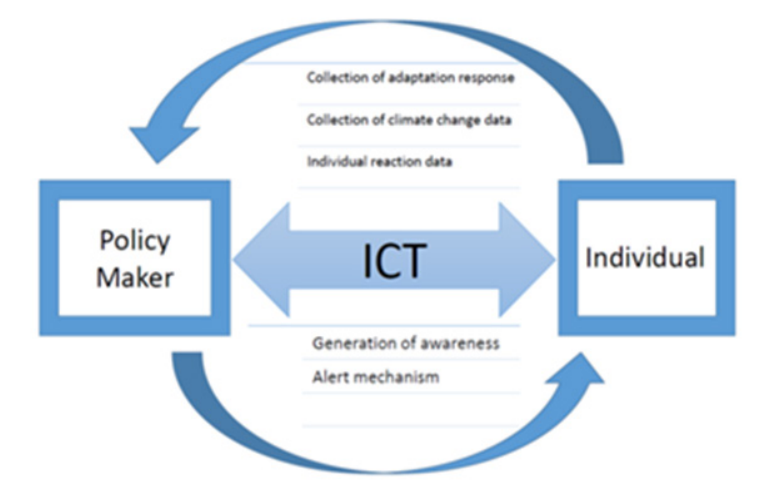

Figure I Role of ICT among Policy maker of climate change adaptation policy and individual.

At present, very few numbers of mobile applications are generating awareness about climate change adaptation. Table 1 identifies such unique mobile applications that are already present in the market and can be of great help in spreading consciousness about climate change adaptation. However the number is significantly low and we need to work upon to improve their number and scope. Hence, it is high time that organisations working day in and day out to deal with the issue of climate change come together and contemplate over the usefulness of using mobile applications in spreading awareness through mobile applications. Along with that, we may even collect response or reaction data at individual level regarding the effects of climate change on each of them through applications, which would in return provide them solutions to deal with such situations and help the policy makers and researchers to come up with a better statistics for further reference and analysis. For example, it is noted that the eArik project staff had to regularly travel to places to undertake field visits to observe crop conditions and the diagnosis of pests, diseases, nutrient deficiencies and physiological problems which incurred a cost of Rs.300000 (US $\$ 6,077)^{7}$ while they could have made a mobile application at a considerably lower price to collect the data from the farmers regarding the same and store it in a database for future references (Figure 1).

\section{Conclusion}

Mobile applications have not yet been effectively integrated when it comes to spreading general awareness among citizens regarding climate change adaptation policies and strategies. Considering the rapid dependency of human beings on mobile applications for every small thing in their day to day life, we must realise how crucial they can be in creating awareness regarding the impact of climate change and adaptation and plan to incorporate them in our strategies and policies at the earliest. The inclusion of mobile applications in climate change adaptation may not only help the commoners to contribute in the process of climate change adaptation but the policy makers and researchers as well by merging societal climate needs with individual climate actions to address this serious impediment to our wellbeing. With the objective of limiting the rise of global temperature as low as 1.5 degree Celsius, research and development of mobile applications in areas of climate change adaptation which are yet to be explored and exploited must be encouraged. Along with that, multidisciplinary studies on effectivity and efficacy of ICT on adaptation strategies should also be evaluated in future. However, we must consider the fact that a part of the rural population is still ignorant of the smart phones and mobile applications and we need to develop applications that is applicable for all irrespective of their socioeconomic status, geographical location, literacy level or age. Climate change adaptation studies should also excel the opportunity of ICTs specifically mobile apps for reducing Green House Gases emission and therefore enhancing climate friendly best practices.

\section{Acknowledgements}

None.

\section{Conflicts of interests}

The authors declare that there is no conflict of interest.

\section{Funding}

None.

\section{References}

1. UNESCO. Education for Sustainable Development. United Nations Educational, Scientific and Cultural Organization, Paris, France;2014.

2. Intergovernmental Panel on Climate Change. Climate Change 2014 Impacts, Adaptation and Vulnerability: Regional Aspects. Cambridge University Press, USA;2014.

3. Bellard C, Bertelsmeier C, Leadley P, et al. Impacts of climate change on the future of biodiversity. Ecolog lette. 2012;15(4):365-377.

4. Stern NH. The economics of climate change: the Stern review. Cambridge University press, USA;2007.

5. Baker I, Peterson A, Brown G, et al. Local government response to the impacts of climate change:An evaluation of local climate adaptation plans. Landscape and urban planning. 2012;107(2):127-136.

6. Charmantier A, McCleery RH, Cole LR, et al. Adaptive phenotypic plasticity in response to climate change in a wild bird population. Science. 2008;320(5877):800-803.

7. Islam R, Islam R, Mazumder T. Mobile application and its global impact. International Journal of Engineering \& Technology (IJEST). 2010;10(6):72-78.

8. Heeks R. Where next for ICTs and international development. ICTs for development. 2010;29-74.

9. Shafiq F, Ahsan K, AdnanNadeem MS, et al. Role of ICT in climate change monitoring: A review study of ICT based climate change monitoring services. Research Journal of Recent Sciences. 2014;3(12):123130 .

10. Sala $\mathrm{S}$. The role of information and communication technologies for community-based adaptation to climate change. Communication for Sustainable Development Initiative. Technical Paper. 2010;1-47.

11. UNFCCC CC. Climate Change Adaptation Strategies for Local Impact. In United Nations Framework Convention on Climate Change (UNFCCC), Germany;2009. 
12. CSTP. Approaches to Climate Change Adaptation November. Task Force Report on Science and Technology Diplomatic Strategy, Council for Science and Technology Policy (CSTP), Japan; 2010.

13. Few R, Brown K, Tompkins EL. Public participation and climate change adaptation: avoiding the illusion of inclusion. Climate policy. 2007;7(1):46-59.

14. WHO. Raising awareness on climate change mitigation and adaptation policies in all sectors. World Health Organisation (WHO), Europe;2017.

15. Sampei Y, Aoyagi-Usui M. Mass-media coverage, its influence on public awareness of climate-change issues, and implications for Japan's national campaign to reduce greenhouse gas emissions. Global Environmental Change. 2009;19(2):203-212.

16. IDRC \& CDI. ICTs and Agricultural Adaptation to Climate Change Climate Change, Innovation \& ICTs Project. International Development Research Centre (IDRC) and Centre for Development Informatics (CDI), University of Manchester, UK;2011.

17. Line B. India to Have 243 Million Internet Users by June. 2014:IAMAI; 2014.

18. UNFCCC CC. Impacts, vulnerabilities and adaptation in developing countries. In United Nations Framework Convention on Climate Change (UNFCCC), Germany; 2007.

19. Elson J, Estrin D. Sensor networks:a bridge to the physical world. In Wireless sensor networks. 2004. p. 3-20.
20. Coyle D, Meier P. New technologies in emergencies and conflicts:the role of information and social networks, USA; 2009.

21. AMARC. Annual report 2008 the year of community radio World Association of Community Radio Broadcasters, AMARC, Canada; 2008.

22. Chanawongse K. The next round of education reform by the Thai government and the four pillars of education. Journal of Administration and Development, Mahasarakham University. 2009;1(2):7-14.

23. Wattegama C. ICT for disaster management, United Nations Development Programme-Asia-Pacific Development Information Programme (UNDP-APDIP). 2007.

24. Samarajiva R. Policy Commentary: Mobilizing information and communications technologies for effective disaster warning:lessons from the 2004 tsunami. New Media \& Society. 2005;7(6):731-747.

25. Census. Government of India. 2011.

26. Simpson MC, Gössling S, Scott D, et al. Climate change adaptation and mitigation in the tourism sector: frameworks, tools and practices. Climate change adaptation and mitigation in the tourism sector: frameworks, tools and practices. UNEP, University of Oxford, UNWTO, WMO:Paris, France; 2008.

27. The Committee on Approaches to Climate Change Adaptation., India. 2010 .

28. World Bank. World development Report. Washington, DC, United States. 2010. 